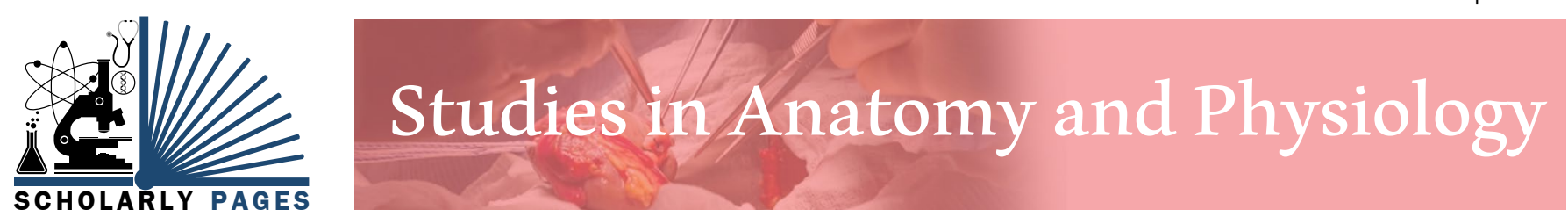

\title{
Gitelman Syndrome: What the Clinician Needs to know
}

\section{Panagiotopoulou TV, Filippatos TD and Elisaf MS*}

\author{
Department of Internal Medicine, School of Medicine, University of loannina, Greece
}

\begin{abstract}
Gitelman syndrome has a prevalence of 1-10/40,000, representing the most common inherited disease of renal tubules. It is due to inactivating mutations of the SLC12A3 gene that encodes the thiazide-sensitive Sodium Chloride Cotransporter (NCC) located in the apical membrane of the distal convoluted tubules, resulting in hypokalemic metabolic alkalosis associated with hypomagnesemia and hypocalciuria. Although it is generally considered a benign tubular disease, a number of complications have been observed in some patients. Increased sodium intake along with a diet rich in potassium and magnesium is essential, but a number of patients requires intravenous potassium or magnesium infusion. In certain patients, amiloride, spironolactone, eplerenone, or renin angiotensin system blockers can be administered.
\end{abstract}

Keywords

Gitelman syndrome, Potassium, Hypokalemia, Metabolic alkalosis, Hypomagnesemia, Hypocalciuria

Gitelman syndrome is the most common autosomal recessive inherited disease of renal tubules with a prevalence of 1-10/40,000. It is characterized by hypokalemic metabolic alkalosis associated with hypomagnesemia and hypocalciuria [1-4]. The disease is due to inactivating mutations of the SLC12A3 gene that encodes the thiazide-sensitive Sodium Chloride Cotransporter (NCC) located in the apical membrane of the distal convoluted tubules [5-7]. Less often, the condition results from mutations in the CLCNKB gene encoding the chloride channel $\mathrm{ClC}-\mathrm{Kb}$, the cause of classic Bartter syndrome [1]. The detection of biallelic inactivating SLC12A3 mutations (currently used methods have high sensitivity and specificity) is crucial for the diagnosis of Gitelman syndrome, but in patients who do not have two mutations in SLC12A3 the clinical sensitivity (proportion of positive tests if the disease is present) is $65 \%$ to $80 \%$. Available next generation sequencing gene panels should at least include the SLC12A3, CLCNKB, and HNF1B genes [1]. Certain founder mutations are observed in populations such as European Gypsies and genetic testing can establish the diagnosis [8-10]. It should be mentioned that there is weak association between genotype and clinical phenotype in Gitelman syndrome.

Gitelman syndrome is usually detected during adolescence or adulthood in patients with symptoms re- lated to the coexisting electrolyte abnormalities (Table 1) $[1,11]$. Most of these clinical findings are related to chronic hypokalemia and hypomagnesemia which can be identified in serum chemistry and can help in the diagnosis of the syndrome (Table 2) $[1,12,13]$. It should be mentioned that even though it was initially regarded as a benign tubular disease, a number of complications have been observed in some patients with Gitelman syndrome (Table 3) [1,14-23].

Gitelman syndrome should be differentiated from acquired causes of hypokalemic nonperiodic paralysis, tubulopathies due to diuretic abuse, bulimia nervosa or chronic vomiting, autoimmune disorders and drugs, from genetic disorders such as Bartter syndrome as well as diseases arisen from mutations in the $\mathrm{KCNJ} 10$ and HNF1 $\beta$ genes (Table 4) [24-31].

*Corresponding author: Professor Moses S Elisaf, Department of Internal Medicine, School of Medicine, University of Ioannina, Staurou Niarchou Avenue, 45110 loannina, Greece, Tel: +302651007509, Fax: +302651007016, E-mail: melisaf54@gmail.com

Received: April 07, 2017; Accepted: May 31, 2017; Published online: June 02, 2017

Citation: Panagiotopoulou TV, Filippatos TD, Elisaf MS (2017) Gitelman Syndrome: What the Clinician Needs to know. Stud Anat Physiol 1(1):1-4

Copyright: (c) 2017 Panagiotopoulou TV, et al. This is an open-access article distributed under the terms of the Creative Commons Attribution License, which permits unrestricted use, distribution, and reproduction in any medium, provided the original author and source are credited. 
Table 1: Clinical and electrocardiographic manifestations in Gitelman syndrome.

- Muscle weakness-fatigue-dizziness

- Cramps-occasionally rhabdomyolysis

- Salt craving

- Nocturia-thirst-polydipsia

- Paresthesia-numbness

- Low blood pressure

- Carpopedal spasms-tetany

- Gastrointestinal symptoms (intestinal paresis, vomiting, constipation)

- In some patients arthritis due to chondrocalcinosis is observed

- In a few cases early onset of the disease associated with failure of thrive and growth retardation as in Barrter syndrome is found

- Ataxia

- Prolonged QT interval in the electrocardiogram-cardiac arrhythmias

Table 2: Usual laboratory findings in patients with Gitelman syndrome.

- Hypokalemia (serum $\mathrm{K}^{+}<3.5 \mathrm{mmol} / \mathrm{L}$ ) associated with inappropriate kaliuresis (potassium/creatinine in a random urine specimen $>18 \mathrm{mmol} / \mathrm{mg}$ )

- Hypomagnesemia (serum magnesium $<0.7 \mathrm{mmol} / \mathrm{L}$ ) associated with renal magnesium wasting (fractional magnesium excretion $>4 \%$ )

- Hypocalciuria (calcium/creatinine in a random urine specimen $<0.07 \mathrm{mg} / \mathrm{mg}$ )

- Metabolic alkalosis

- Increased chloride excretion (fractional chloride excretion > $0.5 \%)$

- Hyperreninemia

- Hypophosphatemia (occasionally)

- Genetic diagnosis: Inactivating mutations in the SLC12A3 gene encoding the thiazide sensitive Sodium-Chloride Cotransporter (NCC)

Table 3: Complications in patients with Gitelman syndrome.

- Cardiac arrhythmias and prolonged QT interval due to coexistent hypokalemia and hypomagnesemia

- Chondrocalcinosis leading to pseudogout

- Sclerochoroidal calcifications

- Renal dysfunction (hypokalemic nephropathy or due to hyperreninemic hyperaldosteronism)

- Glucose intolerance due to coexistent hypokalemia/hypomagnesemia (rarely)

- Hypokalemic rhabdomyolysis (very rare)

Increased sodium intake along with a diet rich in potassium and magnesium is essential for patients' management. Additionally, oral potassium and magnesium supplementation is needed in most patients aiming at increasing serum potassium and magnesium levels $(>3$ $\mathrm{mmol} / \mathrm{l}$ and $0.6 \mathrm{mmol} / \mathrm{l}$, respectively) [1,32-34].The dose of these supplements should be carefully individualized to avoid their side effects. In severe electrolyte imbalanc-
Table 4: Differential diagnosis in patients with suspected Gitelman syndrome.

\section{Genetic disorders}

- Barrter syndrome: normal magnesium levels are commonly observed, other common findings include young age, failure to thrive, and polyuria

- Mutations in the KCNJ10 gene coding for the KCNJ10/ Kir4 (an autosomal resessive disorder characterized by the EAST syndrome [epilepsy, ataxia, sensozineural deafness and tubulopathy])

- Mutations in HNF1 $\beta$ gene coding for the transcription factor HNF1- $\beta$ (dominant mode of inheritance). Other clinical manifestations are common (early renal disease, renal cysts, maternity onset diabetes mellitus, increased transaminases and urogenital malformations)

\section{Acquired disorders}

- Diuretics abuse: a urine screen for diuretics is useful

- Bulimia nervosa and chronic vomiting: urinary chloride levels are usually $<25 \mathrm{mEq} / \mathrm{L}$

- Autoimmune disorders such as Sjogren's syndrome (appropriate tests are necessary)

- Drugs such as cisplatin: drug history is mandatory

Table 5: Treatment of Gitelman syndrome.

- Increased $\mathrm{NaCl}$ intake, diet rich in $\mathrm{K}^{+}$and $\mathrm{Mg}^{2+}$

- Oral potassium supplementation (mainly $\mathrm{KCl} ;>40 \mathrm{mEq} / \mathrm{d}$ with meals; target: serum potassium $>3 \mathrm{mEq} / \mathrm{L}$

- In severe symptomatic cases intravenous $\mathrm{KCl}$ should be carefully administered in hypotonic saline solutions $(<50$ $\mathrm{mmol} / \mathrm{L}$ at a rate of $<10 \mathrm{ml} / \mathrm{h}$ )

- Oral magnesium supplementation (mainly organic salts, such as aspartate, citrate, lactate or $\mathrm{MgCl}_{2} ; 300 \mathrm{mg} / \mathrm{d}$ (12.24 mmol/L) in 2-4 doses (osmotic diarrhea is a common adverse effect); target: serum magnesium $>0.6$ $\mathrm{mmol} / \mathrm{l}$

- In severe symptomatic cases intravenous infusion of $\mathrm{MgCl}_{2}$ or $\mathrm{MgSO}_{4}$ is suggested

- Potassium sparing diuretics, such as spironolactone, eplerenone (50 $\mathrm{mg} \times 2 / \mathrm{d}$ ) or amiloride (up to $20 \mathrm{mg} / \mathrm{d}$ ); special care to avoid natriuresis and hypotension is mandatory

- Other drugs like renin angiotensin system blockers; however increased natriuresis associated with hypotension is a common side effect

- Non-steroidal anti-inflammatory drugs or COX-2 inhibitors; however long term adverse effects limit their long-term administration

es, intravenous potassium or magnesium infusion is indicated. In some patients with persistent hypokalemia, potassium sparing diuretics, such as amiloride, spironolactone or eplerenone can be administered [35-37]. Other drugs, such as renin angiotensin system blockers or nonsteroidal anti-inflammatory agents have been used in case reports [36,38,39]. Chronic hypokalemia-induced interstitial nephropathy increases the risk of chronic renal failure that requires clinical and laboratory monitoring. Finally, special care is indicated in pregnant women with Gitelman syndrome as well as in patients undergo- 
ing anesthesia because in these populations electrolyte derangements increase complications risk [40,41]. The family character of the affection should lead clinicians to also test family members of patients with Gitelman syndrome (Table 5).

\section{Conflict of Interest}

This review was written independently. Professor MS Elisaf reports personal fees from ASTRA ZENECA, grants and personal fees from MSD, personal fees from PFIZER, ABBOTT, SANOFI, BOEHRINGER INGELHEIM, ELI LILLY, GSK. The authors have given talks and attended conferences sponsored by various pharmaceutical companies, including Bristol-Myers Squibb, Pfizer, Lilly, Abbott, Amgen, AstraZeneca, Novartis, Vianex, Teva and MSD.

\section{References}

1. Blanchard A, Bockenhauer D, Bolignano D, et al. (2017) Gitelman syndrome: consensus and guidance from a Kidney Disease: Improving Global Outcomes (KDIGO) Controversies Conference. Kidney Int 91: 24-33.

2. Knoers NV (2006) Gitelman syndrome. Adv Chronic Kidney Dis 13: 148-154.

3. Nine VAM Knoers, Elena N Levtchenko (2008) Gitelman syndrome. Orphanet J Rare Dis 3: 22.

4. Bettinelli A, Bianchetti MG, Girardin E, et al. (1992) Use of calcium excretion values to distinguish two forms of primary renal tubular hypokalemic alkalosis: Bartter and Gitelman syndromes. J Pediatr 120: 38-43.

5. Hsu YJ, Yang SS, Chu NF, et al. (2009) Heterozygous mutations of the sodium chloride cotransporter in Chinese children: prevalence and association with blood pressure. Nephrol Dial Transplant 24: 1170-1175.

6. Takeuchi $\mathrm{Y}$, Mishima E, Shima H, et al. (2015) Exonic mutations in the SLC12A3 gene cause exon skipping and premature termination in Gitelman syndrome. J Am Soc Nephrol 26: 271-279.

7. Vargas Poussou R, Dahan K, Kahila D, et al. (2011) Spectrum of mutations in Gitelman syndrome. J Am Soc Nephrol 22: 693-703.

8. Coto E, Rodriguez J, Jeck N, et al. (2004) A new mutation (intron $9+1 \mathrm{G}>\mathrm{T}$ ) in the SLC12A3 gene is linked to Gitelman syndrome in Gypsies. Kidney Int 65: 25-29.

9. Bouwer ST, Coto E, Santos F, et al. (2007) The Gitelman syndrome mutation, IVS9+1G $>\mathrm{T}$, is common across Europe. Kidney Int 72: 898.

10. Gil-Pena H, Coto E, Santos F, et al. (2017) A new SLC12A3 founder mutation (p.Val647Met) in Gitelman's syndrome patients of Roma ancestry. Nefrologia.

11. Riveira Munoz E, Chang Q, Bindels RJ, et al. (2007) Gitelman's syndrome: towards genotype-phenotype correlations?. Pediatr Nephrol 22: 326-332.

12. Balavoine AS, Bataille $P$, Vanhille $P$, et al. (2011) Phenotype-genotype correlation and follow-up in adult patients with hypokalaemia of renal origin suggesting Gitelman syndrome. Eur J Endocrinol 165: 665-673.
13. Kim YK, Song HC, Kim WY, et al. (2008) Acquired Gitelman syndrome in a patient with primary Sjogren syndrome. Am J Kidney Dis 52: 1163-1167.

14. Bourcier T, Blain P, Massin P, et al. (1999) Sclerochoroidal calcification associated with Gitelman syndrome. Am J Ophthalmol 128: 767-768.

15. von Vigier RO, Ortisi MT, La Manna A, et al. (2010) Hypokalemic rhabdomyolysis in congenital tubular disorders: a case series and a systematic review. Pediatr Nephrol 25: 861-866.

16. Bettinelli A, Tosetto C, Colussi G, et al. (2002) Electrocardiogram with prolonged QT interval in Gitelman disease. Kidney Int 62: 580-584.

17. Ren H, Qin L, Wang W, et al. (2013) Abnormal glucose metabolism and insulin sensitivity in Chinese patients with Gitelman syndrome. Am J Nephrol 37: 152-157.

18. Calo LA, Maiolino G, Naso A, et al. (2015) The association of systemic oxidative stress with insulin resistance: mechanistic insights from studies in Bartter's and Gitelman's syndromes. Clin Endocrinol 83: 994-995.

19. Demoulin N, Aydin S, Cosyns JP, et al. (2014) Gitelman syndrome and glomerular proteinuria: a link between loss of sodium-chloride cotransporter and podocyte dysfunction? Nephrol Dial Transplant 29: 117-120.

20. Walsh SB, Unwin E, Vargas Poussou R, et al. (2011) Does hypokalaemia cause nephropathy? An observational study of renal function in patients with Bartter or Gitelman syndrome. QJM 104: 939-944.

21. Vigano C, Amoruso C, Barretta F, et al. (2013) Renal phosphate handling in Gitelman syndrome--the results of a case-control study. Pediatr Nephrol 28: 65-70.

22. Pachulski RT, Lopez F, Sharaf R (2005) Gitelman's not-sobenign syndrome. N Engl J Med 353: 850-851.

23. Calo L, Punzi L, Semplicini A (2000) Hypomagnesemia and chondrocalcinosis in Bartter's and Gitelman's syndrome: review of the pathogenetic mechanisms. Am J Nephrol 20: 347-350.

24. Panichpisal K, Angulo Pernett F, Selhi S, et al. (2006) Gitelman-like syndrome after cisplatin therapy: a case report and literature review. BMC Nephrol 7: 10.

25. Schwarz C, Barisani T, Bauer E, et al. (2006) A woman with red eyes and hypokalemia: a case of acquired Gitelman syndrome. Wien Klin Wochenschr 118: 239-242.

26. Jeck N, Konrad M, Peters M, et al. (2000) Mutations in the chloride channel gene, CLCNKB, leading to a mixed Bartter-Gitelman phenotype. Pediatr Res 48: 754-758.

27. Ji W, Foo JN, O'Roak BJ, et al. (2008) Rare independent mutations in renal salt handling genes contribute to blood pressure variation. Nat Genet 40: 592-599.

28. Adalat S, Woolf AS, Johnstone KA, et al. (2009) HNF1B mutations associate with hypomagnesemia and renal magnesium wasting. J Am Soc Nephrol 20: 1123-1131.

29. Bockenhauer D, Feather S, Stanescu HC, et al. (2009) Epilepsy, ataxia, sensorineural deafness, tubulopathy, and KCNJ10 mutations. N Engl J Med 360: 1960-1970.

30. Persu A, Lafontaine JJ, Devuyst O (1999) Chronic hypokalaemia in young women--it is not always abuse of diuretics. Nephrol Dial Transplant 14: 1021-1025. 
Citation: Panagiotopoulou TV, Filippatos TD, Elisaf MS (2017) Gitelman Syndrome: What the Clinician Needs to know. Stud Anat Physiol 1(1):1-4

31. Sung CC, Cheng CJ, Chiang WF, et al. (2015) Etiologic and therapeutic analysis in patients with hypokalemic nonperiodic paralysis. Am J Med 128: 289-296.

32. Ranade VV, Somberg JC (2001) Bioavailability and pharmacokinetics of magnesium after administration of magnesium salts to humans. Am J Ther 8: 345-357.

33. Robinson CM, Karet Frankl FE (2017) Magnesium lactate in the treatment of Gitelman syndrome: patient-reported outcomes. Nephrol Dial Transplant 32: 508-512.

34. Huang CL, Kuo E (2007) Mechanism of hypokalemia in magnesium deficiency. J Am Soc Nephrol 18: 2649-2652.

35. Ito Y, Yoshida M, Nakayama M, et al. (2012) Eplerenone improved hypokalemia in a patient with Gitelman's syndrome. Intern Med 51: 83-86.

36. Blanchard A, Vargas-Poussou R, Vallet M, et al. (2015) Indomethacin, amiloride, or eplerenone for treating hypo- kalemia in Gitelman syndrome. J Am Soc Nephrol 26: 468475.

37. Morton A (2008) Eplerenone in the treatment of Gitelman's syndrome. Intern Med J 38: 377.

38. Mayan H, Gurevitz O, Farfel Z (2002) Successful treatment by cyclooxyenase-2 inhibitor of refractory hypokalemia in a patient with Gitelman's syndrome. Clin Nephrol 58: 73-76.

39. Liaw LC, Banerjee K, Coulthard MG (1999) Dose related growth response to indometacin in Gitelman syndrome. Arch Dis Child 81: 508-510.

40. Calo LA, Caielli P (2012) Gitelman's syndrome and pregnancy: new potential pathophysiological influencing factors, therapeutic approach and materno-fetal outcome. J Matern Fetal Neonatal Med 25: 1511-1513.

41. Mascetti L, Bettinelli A, Simonetti GD, et al. (2011) Pregnancy in inherited hypokalemic salt-losing renal tubular disorder. Obstet Gynecol 117: 512-516. 